\title{
Successes and Failures of Family Business in Slovakia
}

\author{
Alena Tóthová ${ }^{*}$, and Miroslav Tóth ${ }^{2}$ \\ ${ }^{1}$ University of Economics in Bratislava, Faculty of Business Management, Department of Business \\ Finance, Dolnozemská cesta 1/b, 85235 Bratislava, Slovak Republic \\ ${ }^{2}$ University of Economics in Bratislava, Faculty of Business Management, Department of Business \\ Finance, Dolnozemská cesta 1/b, 85235 Bratislava, Slovak Republic
}

\begin{abstract}
Family businesses are part of the world's economies, with an estimated $70-90 \%$ share of total performance. The history of family business in Slovakia is not continuous, so we can examine its level from the last 30 years of experience at most. The paper is focused on research of financial results of Slovak family enterprises, their confrontation with other types of enterprises, searching for trends in the level of their financial indicators and finally on the dependence between results and environment. In the research were used several methods, from which we can name mainly analysis, synthesis, comparison, mathematical-statistical methods. The obtained outputs are intended to identify strengths and weaknesses of family business in Slovakia.
\end{abstract}

\section{Introduction}

The tradition of family business in Czechoslovakia was violently discontinued during socialism, but after 1989, the family business of family members started to slowly start again. The beginnings were difficult because most Slovaks did not have enough professional knowledge or the necessary skills for doing business. The isolation of Slovakia has caused the loss of an overview of the level and forms of business in the global world. Despite these obstacles, family businesses have gradually become an important component of the Slovak economy over the past thirty years. The following data briefly characterizes the importance of Slovak family businesses.

\subsection{Current state of family business in Slovakia}

An important source of up-to-date data on Slovak family businesses is the studies of SBA Slovak Business Agency, an agency focused on supporting small and medium-sized enterprises. Interesting knowledge is also brought by repeatedly conducted surveys of consulting company KPMG International with a global scope, directly focused on family business. Trustworthy facts about family businesses are complemented by surveys by PwC (PricewaterhouseCoopers). Outputs of the above companies declare that about one-eighth

\footnotetext{
*Corresponding author: alena.tothova@euba.sk,
} 
of family businesses in Slovakia are medium-sized enterprises, approximately $15 \%$ are small enterprises and up to $70 \%$ are micro-enterprises. Much of the family business is already established on the market, as $34 \%$ of respondents surveyed have a history of more than 20 years and another $32 \%$ are over 10 years old. In terms of the preferred form of family business in Slovakia, the prevalence of the use of limited liability companies, which is seen by up to $73 \%$ of family businesses, can be seen. More than half of family businesses operate by owning only one family member. The importance of family businesses in the European context is clearly stated by the European Commission's estimates of a $60 \%$ share of family businesses in all European businesses. Family businesses themselves are aware of their strength. Most think that they provide stability to the wider economy. The characteristics of family businesses, their strengths and weaknesses, succession problems, profitability, competitive struggle, the struggle for skilled labour, innovation and technological progress, the challenges of penetrating international markets, the imperfections of legislation on this type of business and many other open In its scientific work, questions are addressed not only by a significant part of the professional public [112], but also by many representatives of practice.

Presented state of family business in Slovakia, combined with the state of family business in the European context, further extend the knowledge stemming from the research of financial indicators of family businesses. The range of financial indicators is very broad and therefore the assessment of the status of family businesses from a financial point of view can be very diverse. The following is a brief illustration of what the financial indicators on family businesses reveal.

\subsection{Financial Indicators of Slovak Family Enterprises}

Financial indicators provide an indication of the level of success / failure of family businesses. By examining the financial indicators, it is possible to identify the financial condition of family businesses, its development trends, the complexity and nature of interrelationships between the results of family businesses, the dependence of financial results and the degree of severity of the dependence.

For research of the mentioned areas we chose family enterprises engaged in industrial production, namely the production of grape wine (SK NACE 11020). Industrial production is the backbone of the Slovak economy, which is also reflected in the selection of a sample of family businesses for research. The production of grape wine in Slovakia has been internationally successful in recent years, it has the potential of growth, so it is important to deal with the financial condition of family businesses in the given industry. The sample of family businesses examined is linked by several characteristics. These are family businesses with the same activity, employing 10 to 19 employees, with a turnover of up to $€$ 0.8 million.

Table 1. GDP of Slovakia quantified by expenditure method.

\begin{tabular}{|l|c|c|c|c|c|c|c|c|c|c|}
\hline Indicator & $\mathbf{2 0 1 8}$ & $\mathbf{2 0 1 7}$ & $\mathbf{2 0 1 6}$ & $\mathbf{2 0 1 5}$ & $\mathbf{2 0 1 4}$ & $\mathbf{2 0 1 3}$ & $\mathbf{2 0 1 2}$ & $\mathbf{2 0 1 1}$ & $\mathbf{2 0 1 0}$ & $\mathbf{2 0 0 9}$ \\
\hline $\begin{array}{l}\text { (1) GDP } \\
\text { (1=2+3+4-5) }\end{array}$ & 89721 & 84517 & 81038 & 79758 & 76256 & 74355 & 73484 & 71214 & 68093 & 64096 \\
\hline $\begin{array}{l}\text { (2) Final } \\
\text { consumption } \\
\text { expenditure }\end{array}$ & 66882 & 63206 & 59969 & 57960 & 55998 & 54630 & 54237 & 52735 & 52048 & 51062 \\
\hline $\begin{array}{l}\text { (3) Gross } \\
\text { fixed capital } \\
\text { formation }\end{array}$ & 21022 & 19461 & 18679 & 19346 & 16584 & 15558 & 15192 & 17977 & 16256 & 13141 \\
\hline \begin{tabular}{l} 
(4) Export \\
\hline (5) Import
\end{tabular} & 86213 & 80381 & 75955 & 73396 & 69788 & 69608 & 66897 & 60543 & 52647 & 43608 \\
\hline
\end{tabular}


The Slovak economy and the environment of grape production in Slovakia are represented by the indicators shown in Tables 1 and 2, taken from the SO SR. Statistical office of the Slovak Republic

The data in Table 1 show the uneven trend in Slovakia's GDP growth. The main reasons for GDP growth have changed over time. In most cases, the main driver of GDP was investment, then exports and sometimes domestic consumption. The contribution of grape wine production to the Slovak economy is shown in Table 2.

Table 2. Selected financial indicators of beverage production.

\begin{tabular}{|l|r|r|r|r|r|r|r|r|r|r|}
\hline Indicator & \multicolumn{1}{c|}{$\mathbf{2 0 1 8}$} & \multicolumn{1}{c|}{$\mathbf{2 0 1 7}$} & $\mathbf{2 0 1 6}$ & $\mathbf{2 0 1 5}$ & $\mathbf{2 0 1 4}$ & $\mathbf{2 0 1 3}$ & $\mathbf{2 0 1 2}$ & $\mathbf{2 0 1 1}$ & $\mathbf{2 0 1 0}$ & \multicolumn{2}{c|}{$\mathbf{2 0 0 9}$} \\
\hline GVA & 80495 & 75786 & 72948 & 71777 & 68843 & 67265 & 66775 & 64088 & 61659 & 57994 \\
\hline GVA 11 & 213 & 193 & 193 & 188 & 209 & 195 & 206 & 202 & 221 & 232 \\
\hline Share 11 & 0,26 & 0,25 & 0,26 & 0,26 & 0,30 & 0,29 & 0,31 & 0,32 & 0,36 & 0,40 \\
\hline
\end{tabular}

Explanatory notes: 11 - Division beverage industry, GVA - gross value added

The trend of beverage production has a different dynamics than the GDP of Slovakia. In the selected time series you can see a repeated alternation of the decline with the increase in beverage production. Since 2016, the situation in the production of beverages is already more favourable. There was no drop in the performance of the division. The last row of the table contains data from the confrontation of beverages production with the overall output of Slovakia. The following presentation of the research relates solely to the financial condition of the beverage industry and to the activities of family businesses in this division. First of all, we have to look at the statistically processed financial results of the beverage companies with a turnover of up to $€ 0.8$ million (these are the companies with the lowest turnover).

Table 3. Financial indicators of beverage enterprises.

\begin{tabular}{|l|r|r|r|r|r|r|r|r|r|r|}
\hline Indicator & $\mathbf{2 0 1 8}$ & $\mathbf{2 0 1 7}$ & $\mathbf{2 0 1 6}$ & $\mathbf{2 0 1 5}$ & $\mathbf{2 0 1 4}$ & $\mathbf{2 0 1 3}$ & $\mathbf{2 0 1 2}$ & $\mathbf{2 0 1 1}$ & $\mathbf{2 0 1 0}$ & $\mathbf{2 0 0 9}$ \\
\hline L3 & 1,56 & 1,75 & 1,37 & 1,19 & 1,11 & 1,22 & 1,31 & 1,15 & 1,19 & 1,11 \\
\hline DOZ & 0,00 & 0,36 & 2,53 & 6,39 & 12,12 & 28,18 & 23,75 & 12,20 & 20,37 & 11,41 \\
\hline DIP & 39,87 & 43,53 & 55,41 & 63,45 & 84,22 & 83,37 & 98,88 & 63,72 & 89,24 & 62,78 \\
\hline DIKPzOS & 14,13 & 15,00 & 25,99 & 26,03 & 31,31 & 32,53 & 39,85 & 22,03 & 25,54 & 25,61 \\
\hline DSZ & 257,39 & 418,64 & 380,77 & 493,02 & 543,19 & 457,29 & 488,35 & 465,56 & 479,90 & 503,07 \\
\hline DSKZzOS & 22,88 & 18,93 & 24,66 & 29,52 & 33,09 & 42,85 & 57,76 & 30,43 & 33,36 & 41,51 \\
\hline T / A & 0,56 & 0,36 & 0,45 & 0,35 & 0,32 & 0,28 & 0,22 & 0,27 & 0,20 & 0,26 \\
\hline ZA & 58,98 & 51,66 & 57,80 & 61,66 & 67,44 & 63,65 & 63,33 & 63,76 & 57,52 & 61,20 \\
\hline DZA & 0,00 & 0,00 & 0,00 & 0,00 & 0,00 & 0,00 & 0,00 & 0,00 & 0,00 & 0,02 \\
\hline TZ & 35,43 & & 77,34 & 59,75 & 130,14 & 160,81 & 61,60 & & & 55,08 \\
\hline ROE & 0,00 & $-0,73$ & $-1,92$ & $-0,87$ & $-0,12$ & $-0,03$ & 0,00 & $-0,44$ & $-1,45$ & 0,00 \\
\hline ROA & 0,00 & $-0,36$ & $-0,67$ & $-0,28$ & 0,00 & 0,00 & 0,00 & $-0,10$ & $-0,48$ & 0,00 \\
\hline ROS & 0,05 & $-7,35$ & $-5,52$ & $-3,31$ & $-2,26$ & $-4,70$ & $-0,72$ & $-14,71$ & $-9,58$ & 0,39 \\
\hline PH/T & 15,09 & 12,96 & 15,14 & 20,51 & 21,39 & 13,71 & 15,39 & 15,96 & 13,32 & 14,04 \\
\hline NVH/T & 0,99 & $-3,49$ & $-3,78$ & 1,18 & 0,25 & $-2,47$ & $-0,13$ & $-14,27$ & $-6,18$ & 1,01 \\
\hline
\end{tabular}

Explanatory notes: L3 total liquidity ratios, DOZ inventory turnover, DIP debtor days ratio, DIKPzOS maturity of short-term trade receivables, DSZ creditor days ratio, DSKZzOS maturity of short-term trade payables, T/A asset turnover, ZA debt ratio, DZA long-terms debt ratio, TZ flow indebtedness, 
ROE return on equity, ROA return on assets, ROS return on sales, $\mathrm{PH}$ added value, T sales, NVH newly created value.

Table 3 shows the median values of sectoral enterprises, irrespective of the form of business, taken from the Cribis database, the Universal Register [13].

Smaller sector enterprises are usually overcapitalized and more pronounced in the last three years. Stocks are getting faster and faster, and debt collection is shortened. The financial equilibrium helps them to maintain a longer maturity of liabilities than collection of receivables. Longer maturities than direct debits are also maintained for short-term components. Smaller beverage businesses are gradually less indebted over the ten-year period due to better profitability. They never exceeded the $70 \%$ debt ratio. The debts of these enterprises are in most cases short-term, but the possibility of repaying all debts is weak. Repayment of debts would take several decades. The median profitability of beverage businesses is low. Quite often they even achieve negative profitability. This result is a tax on labour intensiveness and fixed assets. The normal financial situation of the sectoral enterprises surveyed can generally be assessed favourably, as the results did not show any serious shortcomings and the trend of their development is positive. The assessment of the financial performance of the smallest beverage business raises the question: How does family business thrive in such an environment? The basis for the answer to the question is contained in Table 4. The quantification of the data shown in Table 4 was preceded by the search for family-owned grape holders, with a staff of 10 to 19 , with a turnover of up to $€ 0.8$ million from FinStat [14].

Table 4. Financial indicators of family enterprises sector.

\begin{tabular}{|l|r|r|r|r|r|r|r|r|r|r|}
\hline Indicator & $\mathbf{2 0 1 8}$ & $\mathbf{2 0 1 7}$ & $\mathbf{2 0 1 6}$ & $\mathbf{2 0 1 5}$ & $\mathbf{2 0 1 4}$ & $\mathbf{2 0 1 3}$ & $\mathbf{2 0 1 2}$ & $\mathbf{2 0 1 1}$ & $\mathbf{2 0 1 0}$ & $\mathbf{2 0 0 9}$ \\
\hline L3 & 0,86 & 0,88 & 0,97 & 1,03 & 0,97 & 1,56 & 1,82 & 1,71 & 2,11 & 1,58 \\
\hline DOZ & 487,93 & 427,94 & 338,18 & 329,06 & 299,51 & 329,10 & 326,76 & 351,28 & 365,37 & 496,94 \\
\hline DIP & 45,78 & 42,18 & 37,46 & 34,91 & 45,71 & 72,97 & 75,83 & 60,68 & 46,81 & 90,75 \\
\hline DIKPzOS & 29,15 & 36,73 & 29,70 & 34,25 & 41,73 & 36,56 & 41,61 & 49,18 & 45,48 & 56,79 \\
\hline DSZ & 199,54 & 140,74 & 184,97 & 343,54 & 266,72 & 225,45 & 133,85 & 208,08 & 143,25 & 345,85 \\
\hline DSKZzOS & 43,39 & 57,41 & 39,87 & 35,02 & 29,90 & 52,85 & 27,60 & 40,64 & 11,81 & 16,85 \\
\hline T / A & 0,30 & 0,34 & 0,33 & 0,32 & 0,39 & 0,28 & 0,40 & 0,36 & 0,47 & 0,32 \\
\hline ZA & 45,49 & 45,67 & 50,47 & 50,59 & 49,23 & 46,81 & 34,29 & 25,15 & 38,38 & 47,56 \\
\hline DZA & 5,85 & 8,01 & 9,32 & 11,25 & 4,65 & 9,10 & 0,05 & 0,03 & 2,90 & 6,49 \\
\hline $\begin{array}{l}\text { Flow } \\
\text { indebtedness }\end{array}$ & 9,84 & 3,36 & 6,91 & 2,73 & 4,03 & 3,10 & 4,46 & 3,03 & 1,08 & 2,58 \\
\hline ROE & 0,01 & 0,48 & 0,31 & 1,85 & 1,23 & 0,44 & 2,44 & 0,74 & 1,20 & 1,47 \\
\hline ROA & 0,01 & 0,35 & 0,15 & 0,45 & 0,58 & $-0,04$ & 0,30 & 0,20 & 0,36 & 0,04 \\
\hline ROS & 0,02 & 0,02 & 0,00 & 1,32 & 0,01 & $-0,19$ & 0,60 & 0,01 & 0,14 & 0,01 \\
\hline PH/T & 36,98 & 38,49 & 41,49 & 28,53 & 24,33 & 41,55 & 28,59 & 31,92 & 33,45 & 36,08 \\
\hline NVH/T & $-30,65$ & $-15,82$ & $-12,78$ & $-6,59$ & $-8,48$ & $-7,01$ & $-2,27$ & $-7,76$ & $-1,51$ & $-1,52$ \\
\hline
\end{tabular}

After compiling the set of family businesses, it was necessary to calculate their financial indicators, in accordance with the methodology of the Cribis database, the Universal Register. The method of calculating the financial indicators of family businesses was conditioned by the research intentions. The aim of the presented research is to compare the financial results of family enterprises with other comparable enterprises in the industry, to verify their interrelationships, development trends, to recognize the complexity and nature 
of the interrelationships between family enterprises, Finally, we proceeded to quantify the median values of family business indicators. The median values represent whole sets of enterprises and can serve the desired confrontation.

Family grape holdings cannot be permanently overcapitalised. The last three years have shown a discrepancy between current assets and current liabilities. The mismatch undermines the financial stability of the family businesses under review. Removal of stocks has been protracted, and this period has been increasing more and more over the last two years. The scales of financing the selected set of enterprises are partly offset by shorter collection of total receivables compared to the maturity of all liabilities. Significantly longer maturity of liabilities increases the scope for cash inflow into the company. It is assumed that an adequate amount of cash flows into the enterprise during a long maturity period. The supplier-customer relations of family businesses are not so favourably consolidated for them. Only roughly in the last half of the time series will they collect cash more quickly than they use to pay short-term liabilities to suppliers. Immediately after the global crisis and for about the next three years, family businesses were not able to raise funds from their customers in due time. The low turnover of assets is given by the nature of the activity, its demands on the asset. The indebtedness of family businesses has not changed very much over the last ten years and almost does not exceed 50\% at all. The debt portfolio also includes long-term debt, which, given the difficulty of maintaining the stability of financing, can be considered a positive situation.

Table 5. Cohen correlation coefficient interpretation.

\begin{tabular}{|c|c|c|c|}
\hline $\boldsymbol{\rho}_{\mathbf{x y}}$ & Interpretation & $\boldsymbol{\rho}_{\mathbf{x y}}$ & Interpretation \\
\hline $0,0-0,1$ & trivial correlation & $0,5-0,7$ & big \\
\hline $0,1-0,3$ & small & $0,7-0,9$ & very big \\
\hline $0,3-0,5$ & middle & $0,9-1,0$ & almost perfect \\
\hline
\end{tabular}

The strong correlations between the financial results of family businesses and the results of other sectoral enterprises are defined by the data in Tables 6 and 7.

Table 6. Interrelations between indicators of comparison sets of enterprises.

\begin{tabular}{|c|c|c|c|c|c|c|c|c|}
\hline & \multirow{2}{*}{ Indicators } & \multicolumn{7}{|c|}{ Sectoral indicators } \\
\hline & & L3 & DOZ & DIP & DIKPzOS & DSZ & DSKZzOS & $\mathbf{T} / \mathbf{A}$ \\
\hline \multirow{8}{*}{ 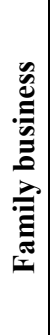 } & $\mathrm{L} 3$ & & 0,788 & 0,694 & & & 0,658 & $-0,827$ \\
\hline & $\mathrm{DOZ}$ & & & $-0,635$ & $-0,660$ & & & \\
\hline & DIP & & & & & & 0,761 & \\
\hline & DIKPzOS & & & & & 0,640 & & $-0,744$ \\
\hline & DSKZzOS & 0,627 & & & & & & \\
\hline & $\begin{array}{l}\text { Flow } \\
\text { indebtedness }\end{array}$ & & & & & $-0,832$ & & 0,878 \\
\hline & ROE & & & 0,649 & 0,674 & 0,705 & 0,704 & $-0,644$ \\
\hline & $\mathrm{NVH} / \mathrm{T}$ & $-0,711$ & 0,681 & 0,751 & 0,699 & 0,891 & 0,654 & $-0,922$ \\
\hline
\end{tabular}

Family businesses are able to handle debt repayment at a reasonable level, except for 2018. Although the profitability of family businesses producing grapes is low, it was only negative in 2013. Profitability affects the nature of the business and its intensity on production factors.

The relationships between the financial results of the surveyed enterprise files can be verified through the MS Excel statistical function, the CORREL function. It has a formula: $=$ correl (array1; array2). It aims to evaluate the intensity of the dependency between the independent variable " $x "$ and the dependent variable " $y$ ". Individual indicators of industrial enterprises represent an independent variable " $x$ " and indicators of family enterprises a 
dependent variable "y". The results of the individual measurements are in the range $<-1 ; 1>$. Based on their position, we can only focus on those that show strong links, whether positive or negative (Table 5). We set the limit of strong dependence at the point „0.6“, resp. "-0.6".

Table 7. Interrelations between indicators of comparison sets of enterprises.

\begin{tabular}{|c|c|c|c|c|c|c|c|c|c|}
\hline & \multirow[b]{2}{*}{ Indicators } & \multicolumn{8}{|c|}{ Sectoral indicators } \\
\hline & & $\mathbf{Z A}$ & DZA & \begin{tabular}{|c|} 
Flow \\
indebtedness \\
\end{tabular} & ROE & ROA & ROS & PH/T & NVH/T \\
\hline \multirow{6}{*}{ 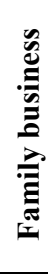 } & $\mathrm{DOZ}$ & & 0,607 & $-0,603$ & & & & & \\
\hline & DIP & & 0,662 & & 0,625 & 0,626 & & & \\
\hline & DIKPzOS & & 0,673 & & & & & & \\
\hline & ZA & & & & & & 0,605 & & 0,745 \\
\hline & ROA & & & & & & & 0,644 & \\
\hline & $\mathrm{PH} / \mathrm{T}$ & & & & & & & $-0,761$ & \\
\hline
\end{tabular}

Numerous strong interrelationships are not confirmed between sectoral results and family-owned grape holdings We can state that the most strongly interrelated indicators are $\mathrm{NVH} / \mathrm{T}, \mathrm{ROE}$ and L3. Nearly perfect negative binding is found exclusively in NVH / T. It seems that on the Slovak beverage market in smaller turnovers, the family businesses producing grapes do not have enough room for realization. In contrast, NVH's increasing share of sales for beverage-producing businesses with different forms of business reduces the share of the grape-producing family. Probably everything is related to competition in the beverage market. If other businesses in the turnover zone of $€ 0.8$ million tear off most of the common cake, the family businesses will remain smaller. The correlations in Tables 6 and 7 are predominantly positive. Among the indicators of the comparative sets of enterprises, mainly a large link was quantified, a little less very large and only in one case cited almost perfect.

Research on the financial condition of family-run grape holdings with lower turnover can be complemented by conclusions from the verification of relations with the macro environment and / or sector / internal environment. Specifically, these are relations with GDP components and typical sectoral indicators, as shown in Table 8.

Table 8. Relationships between family business indicators and external / internal environment.

\begin{tabular}{|l|c|c|c|c|c|c|}
\hline \multicolumn{1}{|c|}{ Indicators } & $\begin{array}{c}\text { Final } \\
\text { consumption } \\
\text { expenditure }\end{array}$ & $\begin{array}{c}\text { Gross } \\
\text { fixed } \\
\text { capital } \\
\text { formation }\end{array}$ & Export & Import & $\begin{array}{c}\text { Sectoral } \\
\text { PP }\end{array}$ & $\begin{array}{c}\text { Sectoral } \\
\text { T }\end{array}$ \\
\hline L3 & $-0,816$ & $-0,672$ & $-0,768$ & $-0,777$ & & \\
\hline DOZ & & & & & $-0,659$ & \\
\hline DIP & $-0,607$ & $-0,821$ & $-0,635$ & $-0,672$ & & \\
\hline DIKPzOS & $-0,813$ & $-0,756$ & $-0,917$ & $-0,907$ & & \\
\hline DSZ & & & & & & $-0,685$ \\
\hline DSKZzOS & 0,624 & & 0,752 & 0,743 & $-0,737$ & \\
\hline Flow indebtedness & 0,766 & & 0,690 & 0,701 & & \\
\hline NVH/T & $-0,924$ & $-0,801$ & $-0,797$ & $-0,839$ & & \\
\hline
\end{tabular}

Explanatory notes: Sectoral PP - Sectoral labour productivity, Sectoral T - Sectoral sales

The internal environment in Table 8 is represented by the indicators of sectoral labour productivity and sectoral revenues. Other indicators (final consumption expenditure, gross 
capital formation, exports, imports) represent the macro environment of Slovakia. The strong impact of the internal environment on the family businesses examined was only confirmed by the turnover of stocks and the repayment of liabilities. Better utilization of the workforce within the sector benefits the grape family business from faster stock picking and short-term trade payables. Increasing labour productivity is reflected in business revenues. Revenue from implementation is due to the removal of production and a larger volume of sales can be better used to pay off liabilities. The impact of the macro environment on the selected family business is somewhat clearer and more numerous. The relationships with the macro-environment are mostly negative. Increasing domestic consumption, increasing investment and exports have demonstrably shortened the collection of all receivables, including trade receivables, to family businesses, but also worsens overall liquidity. The better-named macroeconomic indicators press strongly to extend the maturities of shortterm liabilities to of all debts. Paradoxically, more performance in the economy reduces the share of newly created value of family businesses in sales. What is it given? Nature of activity and competition. Increasing demand hides increasing demand, which all business entities want to use. But the business being monitored is only slightly profitable, almost to the edge, which does not allow businesses to create enough of their own resources. Businesses must therefore seek foreign resources in order to make the most of the growing demand. At the same time, foreign sources are being favoured by favourable conditions on financial markets, materialized in attractive conditions for obtaining foreign sources. Low profitability and more debt must automatically aim to extend the debt settlement period. Better times in the country's economy encourage the optimistic mood of economic agents, and as a result, it may be expected to provide or tolerate a longer reimbursement period by suppliers for higher purchases. What family families producing grape can certainly not be pleased to find is that, despite optimism, rising household spending, increasing investment in long-term assets and more intensive exports, they fail to change the share of newly created value in sales to such an extent as to improve their profitability. Now is the time to draw attention to the competitive struggle between businesses with less turnover in grape production. It turns out that increasing domestic consumption is not necessarily directed towards the production of the most vulnerable family businesses, investment in fixed assets usually reduces operating costs, but also increases the cost of wear and tear. The cost savings are not likely to be so high as to sufficiently exceed labour requirements and the cost of wear and tear on fixed assets.

\section{Conclusion}

The facts presented in this paper clearly demonstrate the importance of family businesses not only for the Slovak economy, but also for the world economy. Family business has its specifics, which brings certain advantages but also disadvantages. Surveys and studies by reputable companies discuss in detail the rules for the functioning of family businesses, their financial decision-making, mentioning unused opportunities and the most important challenges for the future. The knowledge base of the surveys is connected with the results of the examination of financial indicators of a selected sample of Slovak family businesses. The paper deals with the evaluation of financial condition of family businesses, its development trends, mutual relations between the results of their external and internal environment. Presented data and method of their processing are an example of analytical work with parameters of family businesses. 


\section{Acknowledgement}

The article is a partial result of research within the VEGA projects n. 1/0240/20 „Financial Aspects of Sustainable Business - Enterprise Succession Solution for Small and Medium-sized Enterprises“ share $50 \%$ and

VEGA MŠ SR n. 1/0708/20 "Socio-economic determinants of sustainable consumption and production in terms of impact on performance and competitiveness of enterprises" share $50 \%$.

\section{References}

1. B. Maury, Family Ownership and Firm Performance: Emperical Evidence from Western European Corporations. Journal of Corporate Finance 12, pp. 321-341. ISSN 0929-1199. (2006).

2. R. C Anderson, D. M. Reeb, Founding- family ownership and firm performance: Evidence from the S\&P 500. The Journal of Finance 58, Issue 3, pp. 301-1328. ISSN 1540-6261. (2003)

3. K. Birdi et al., The impact of human resource and operational management practices on company productivity: a longitudinal study. Personnel Psychology 61, Issue 3, pp. 467-501. ISSN 1744-6570. F. De Lillo, F. Cecconi, G. Lacorata, A. Vulpiani, Sedimentation speed of inertial particles in laminar and turbulent flows. $E P L, \mathbf{8 4}, 314-$ 381 (2008)

4. B. Leavy, Outsourcing strategy and a learning dilemma. Production and Inventory Management Journal 4, 50-54 (1996).

5. O. Hart, The Costs and Benefits of Ownership: A Theory of Vertical and Lateral Integration. Journal of Political Economy 94, 4, 691-719 (1986).

6. C. Lynch, Logistics Outsoucing - A Management Guide. Council of Logistics Management, Oak Brook (2000).

7. KPMG, Enterprise European family business barometer Succession top of mind as business families eye their legacy 2019 Eighth edition home.kpmg/familybusiness www.europeanfamilybusinesses.eu (2020)

8. E. Arrigo, Global Sourcing in Fast Fashion Retailers: Sourcing Locations and Sustainability Considerations. Sustainability 12, 508 (2020).

9. M. Aoki, Horizontal vs. Vertical Information Structure of the Firm. American Economic Review 76, 5, 971-983 (1986).

10. M. Pankowska, Information Technology Outsourcing Chain: Literature Review and Implications for Development of Distributed Coordination. Sustainability 11, 1460 (2020).

11. A. M. Abubakr, A. T. Abbas, T. Italo, M. S. Soliman, M. Luqman, H. Hegab, Sustainable and Smart Manufacturing: An Integrated Approach. Sustainability 12, 2280 (2020).

12. M. W. Rutherford, D. F. Kuratko, D. T. Holt, Examining the Link Between "Familiness" and Performance: Can the F-PEC Untangle the Family Business Theory Jungle?. Entrepreneurship Theory and Practice 32, pp. 1089-1109. ISSN 1540-6520, (2008)

13. Cribis, Universal register. https://www2.cribis.sk/ExtendedSearch.aspx

14. Finstat, Database of companies and organizations. https://finstat.sk/databaza-firiemorganizacii 